\title{
HAMBATAN-HAMBATAN BELAJAR YANG MEMPENGARUHI HASIL BELAJAR MAHASISWA DALAM PEMBELAJARAN MATA KULIAH DASAR DESAIN JURUSAN IKK FPP UNP
}

\author{
Sherly Septia Suyedi ${ }^{1 *}$, Yenni Idrus ${ }^{2^{*}}$ \\ Program Studi Pendidikan Kesejahteraan Keluarga Jurusan Ilmu Kesejahteraan Keluarga \\ Fakultas Pariwisata dan Perhotelan \\ Universitas Negeri Padang \\ Jl. Prof. Dr. Hamta, Air Tawar Padang, Kel. Air Tawar Barat, Kec. Padang Utara, Kota Padang, Kode Pos 25171 \\ Sumatera Barat. Indonesia \\ Email: sherlyseptia00@gmail.com
}

\begin{abstract}
Abstrak
Penelitian ini dilatarbelakangi oleh waktu perkuliahan yang tidak efektif yaitu dapat dilihat dari seringnya dosen pengampu mata kuliah tidak hadir dalam proses pembelajaran. Perbedaan persepsi antara dosen dengan asisten dosennya yang mengakibatkan mahasiswa menjadi bingung dengan apa yang harus dikerjakan. Materi yang diberikan oleh asisten dosen saat belajar mata kuliah Dasar Desain sulit dimengerti oleg mahasiswa dan tidak ada media pembelajaran yang menjadi standar dalam pembelajaran. Jenis penelitian ini adalah deskriptif kuantitatif. Populasi penelitian adalah seluruh mahasiswa program studi PKK Tata Busana angkatan 2017 yang berjumlah 56 orang. Sampel penelitian adalah semua mahasiswa prodi PKK Tata Busana angkatan 2017 yang telah mengikuti mata kuliah Dasar Desain, yaitu sebanyak 56. Data dikumpulkan dengan kuisioner. Uji coba penelitian menggunakan 60 butir pernyataan, uji coba angket ditemukan 6 pernyataan dibuang karena tidak valid sehingga angket penelitian menggunakan 54 butir pernyataan. Teknik analisa data dengan analisis deskriptif terdiri dari persentase dan TCR. Hasil penelitian menunjukkan bahwa hambatan-hambatan belajar mahasiswa dalam pembelajaran mata kuliah Dasar Desain Jurusan IKK FPP UNP, dilihat dari minat yaitu kemauan mengerjakan tugas, kemauan bertanya, keaktifan dalam diskusi, memanfaatkan kesempatan bertanya, perhatian terhadap materi kurang, kemauan menambah pengetahuan di luar dalam pembelajaran, kurang serius, tidak membuat catatan pinggir, mencatat informasi dan menggarisbawahi catatan. Sedangkan dari kesiapan belajar, faktor penghambat adalah kondisi kesehatan, mahasiswa lesu, kurangnya hasrat dalam belajar, kurang percaya diri dan kurang membaca buku.
\end{abstract}

Kata Kunci: hambatan, hasil belajar, minat belajar.

\begin{abstract}
This research is motivated by ineffective lecture time, which can be seen from the frequency of lecturers who are not present in the learning process. Differences in perceptions between lecturers and assistant lecturers which resulted in students becoming confused about what to do. The material provided by the teaching assistant when studying Basic Design courses is difficult to understand by students and there is no learning media that becomes the standard in learning. This type of research is quantitative descriptive. The study population was all 2017 students of the 2017 Fashion Design PKK study program. The research sample is all 2017 Fashion Design PKK students who have taken Basic Design courses, which are as many as 56. Data were collected by questionnaire. The research trial used 60 items of statements, the questionnaire trial found 6 statements discarded because they were invalid so the research questionnaire used 54 items of statements. Data analysis techniques with descriptive analysis consisted of percentages and TCR. The results showed that the learning barriers of students in basic design learning at the FPP UNP IKK Department, seen from the interests of the willingness to do the task, the willingness to ask questions, activeness in discussion, taking advantage of opportunities to ask, lack of attention to material, willingness to increase knowledge outside learning, less serious, not making marginal notes, recording information and underlining notes. Whereas from learning readiness, the inhibiting factors are health conditions, sluggish students, lack of desire in learning, lack of confidence and lack of reading books.
\end{abstract}

Keywords: hindrance, learning outcome, interest. 


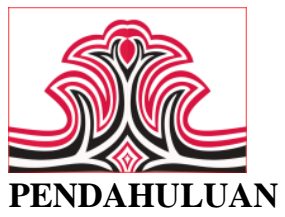

Pendidikan merupakan salah satu aspek terpenting dan perlu untuk dikembangkan. Pendidikan adalah sebuah usaha sadar dan terencana yang bertujuan untuk mewujudkan suasana belajar dan proses pembelajaran agar peserta didik secara aktif dapat mengembangkan potensi dirinya. Untuk dapat mewujudkan masyarakat yang cerdas, kreatif dan terampil maka setiap peserta didik yang dalam hal ini adalah mahasiswa dituntut untuk bisa mempraktikkan, menerapkan dan mengembangkan ilmu pengetahuan yang didapat.

Universitas Negeri Padang (UNP) adalah salah satu perguruan tinggi negeri yang menyelenggarakan pendidikan akademik, profesi dan vokasi dalam bidang kependidikan dan nonkependidikan (Peraturan Akademik UNP, 2015:8). Fakultas Pariwisata dan Perhotelan (FPP) adalah salah satu fakultas yang ada di kampus UNP.

Profil FPP yang terdapat pada website resmi FPP yang diakses pada tanggal 30 Juli 2018, menjelaskan bahwa FPP memiliki tiga jurusan dan lima program studi, yaitu (1) Jurusan Ilmu Kesejahteraan Keluarga (IKK) yang memiliki 3 program studi, yaitu S1 Pendidikan Kesejahteraan Keluarga (S1 Tata Busana dan S1 Tata Boga), D3 Tata Boga dan D3 Tata Busana, (2) Jurusan Tata Rias dan Kecantikan dengan program studi D4 Pendidikan Tata Rias dan Kecantikan dan (3) Jurusan Pariwisata dengan Program Studi D4 Manajemen Perhotelan. Profil FPP tersebut juga dijelaskan bahwa FPP memiliki beberapa tujuan, salah satunya yaitu untuk menghasilkan lulusan yang berilmu, terampil, profesional, tangguh serta berdaya saing global.

Pada proses pembelajaran tentu dosen yang mengajar mengharapkan agar mahasiswanya dapat mencapai hasil belajar yang maksimal. Namun, tidak sedikit juga ditemukan adanya kesulitan belajar yang dialami oleh mahasiswa saat menerima materi perkuliahan sehingga mereka memperoleh hasil belajar yang kurang memuaskan. Dalam pembelajaran, banyak faktor yang dapat mempengaruhi mahasiswa untuk menghambat proses pembelajarannya.

Menurut Slameto (2010:2), "Belajar adalah suatu proses perubahan yaitu perubahan tingkahlaku sebagai hasil interaksi dengan lingkungan dalam memenuhi kebutuhan hidupnya". Perubahan dari sikap mahasiswa sebagai hasil dari interaksi yang dilakukannya dalam lingkungan kampus. Sedangkan pembelajaran yang dijelaskan oleh Rudi (2009:1) merupakan suatu kegiatan yang melibatkan peserta didik dalam upaya memperoleh pengetahuan,
Gorga Jurnal Seni Rupa

Volume 08 Nomor 01 Januari-Juni 2019 p-ISSN: 2301-5942 | e-ISSN: 2580-2380

keterampilan dan nilai-nilai positif dengan memanfaatkan berbagai sumber untuk berlajar.

Dalyono (1997:26) mengungkapkan bahwa hambatan dalam belajar dapat dilihat dari tingkah laku yang menggambarkan kesulitan belajar, yaitu menunjukkan hasil belajar yang rendah dan hasil yang dicapai tidak seimbang dengan usaha yang dilakukan. Sedangkan Slameto (2010:54) menjelaskan bahwa faktor-faktor yang mempengaruhi belajar banyak jenisnya, tetapi dapat digolongkan menjadi dua golongan saja, yaitu (1) faktor internal(faktor yang bersumber dari dalam diri), seperti kesehatan, inteligensi, bakat, minat, perhatian, motivasi kematangan serta kesiapan dan (2) faktor eksternal(faktor yang bersumber dari luar diri), seperti keluarga, sekolah dan masyarakat.

Berdasarkan hal di atas, faktor-faktor yang dapat menghambat belajar mahasiswa kebanyakan terdapat pada mahasiswa itu sendiri, seperti kurangnya motivasi dan minat dari mahasiswa itu sendiri untuk belajar, perhatian tidak sepenuhnya ditujukan pada pelajaran, serta mudahnya mahasiswa terbawa pada lingkungan sekitar seperti ajakan teman untuk berbicara atau bermain saat proses pembelajaran berlangsung.

Hambatan-hambatan yang dialami mahasiswa dalam belajar tersebut nanti akan berpengaruh pada hasil mahasiswa tersebut. Dalam daftar kurikulum mata kuliah tahun 2017 program studi PKK FPP UNP, mata kuliah Dasar Desain merupakan salah satu mata kuliah yang tergolong pada Mata KuliahWajib Program Studi yang dipelajari pada semester 2 dengan bobot 2 sks (1 sks teori dan 1 sks praktek).

Pada pembelajaran mata kuliah Dasar Desain mahasiswa harus dapat berpikir kritis, cerdas dan teliti dalam memahami dan memberikan pengetahuan tentang konsep dasar desain, unsur-unsur desain (garis, arah, bentuk/bidang, tekstur dan warna), prinsip-prinsip desain (irama, keseimbangan, kontras/pusat perhatian dan kesesuaian) dan mampu mengembangkan serta mengungkapkan bahasa rupa (visual) berdasarkan kaidah-kaidah estetika dalam bidang tata busana dengan jujur, cermat dan bertanggung jawab (Silabus Pembelajaran Mata Kuliah Dasar Desain PKK Tata Busana (S1), 2017).

Dari wawancara yang peneliti lakukansecara acak kepada 15 orang mahasiswa PKK Tata Busana angkatan 2017 yang telah selesai mengikuti perkuliahan Dasar Desain pada semester Januari-Juni 2018, menjelaskan bahwa pada mata kuliah Dasar 
Desain dibagi atas tiga seksi. Mereka menerangkan bahwa dalam ketiga seksi pembelajaran mata kuliah Dasar Desain, terdapat dua seksi dalam mata kuliah tersebut yang rata-rata mahasiswanya mendapatkan nilai yang kurang memuaskan. Daftar nilai mahasiswa setiap seksi dapat dilihat pada Tabel 1 berikut:

Tabel 1. Daftar Nilai Mahasiswa Prodi PKK Tata Busana Angkatan 2017 yang Mengikuti Mata Kuliah Dasar Desain

\begin{tabular}{|c|c|c|c|}
\hline \multirow{2}{*}{ Nilai } & \multicolumn{3}{|c|}{ Jumlah Mahasiswa } \\
\cline { 2 - 4 } & Seksi A & Seksi B & Seksi C \\
\hline A & 7 & - & - \\
\hline A- & 7 & 1 & - \\
\hline B+ & 6 & 4 & - \\
\hline B & 5 & 4 & 1 \\
\hline B- & - & 8 & 3 \\
\hline C+ & 1 & 3 & 5 \\
\hline C & - & 3 & 8 \\
\hline C- & - & 2 & 1 \\
\hline D & - & 1 & 4 \\
\hline E & 3 & 2 & 6 \\
\hline Total & 29 & 28 & 28 \\
\hline
\end{tabular}

Dari tabel di atas dapat dijelaskan, bahwa pada seksi A terdapat 29 orang mahasiswa yang mengikuti mata kuliah Dasar Desain dan terdapat tiga (3) orang mahasiswa yang mendapatkan nilai kurang memuaskan yaitu nilai E. Pada seksi ini mahasiswa rata-rata mendapatkan nilai yang memuaskan, yaitu ada masing-masing tujuh (7) orang yang mendapatkan nilai A dan A-, enam (6) orang yang mendapatkan nilai $\mathrm{B}+$, lima (5) orang yang mendapatkan nilai $\mathrm{B}$ dan hanya satu (1) yang mendapatkan nilai $\mathrm{C}+$.

Pada seksi B, terdapat 28 orang mahasiswa yang mengikuti mata kuliah Dasar Desain dan ada lima (5) orang mahasiswa yang mendapatkan nilai yang kurang memuaskan yaitu antara nilai C- hingga E. Pada seksi B, tidak ada mahasiswa yang mendapatkan nilai A, nilai tertinggi yang didapatkan adalah A- dengan berjumlah satu (1) orang. Dan nilai B- adalah nilai yang paling banyak didapatkan oleh mahasiswa pada kelas ini.

Pada seksi C, terdapat 28 orang yang mengikuti mata kuliah Dasar Desain, dimana ada sebelas (11) orang mahasiswa yang mendapatkan nilai yang kurang memuaskan yaitu antara nilai C- hingga E. Nilai tertinggi yang didapat oleh mahasiswa di seksi ini adalah nilai B, yaitu sebanyak satu (1) orang mahasiswa saja. Dan nilai yang paling banyak didapatkan oleh mahasiswa yang belajar di seksi C ini adalah nilai C, yaitu sebnyak delapan (8) orang.

Jadi, dapat disimpulkan bahwa mahasiswa PKK Tata Busana angkatan 2017 yang mengikuti mata kuliah Dasar Desain pada seksi A rata-rata mendapatkan nilai yang memuaskan. Sedangkan mahasiswa yang belajar
Gorga Jurnal Seni Rupa

Volume 08 Nomor 01 Januari-Juni 2019

p-ISSN: 2301-5942 | e-ISSN: 2580-2380

pada seksi B dan C rata-rata dari mereka mendapatkan nilai yang kurang memuaskan.

Dari wawancara yang peneliti lakukan pada mahasiswa yang belajar di seksi B dan C pada mata kuliahDasar Desain adalah sebagai berikut. Menurut mahasiswa yang berinisial $\mathrm{R}$, "Minggu pertama hingga ke-5 perkuliahan dosennya tidak pernah masuk dan pada minggu ke-6 pada saat pertama kali masuk, dosennya langsung memberikan tugas yang seharusnya diberikan sejak minggu pertama".

Mahasiswa lain yang berinisial A juga mengatakan hal yang sama, yaitu "Dosen yang mengajar dasar desain itu baru masuk pada minggu ke-5. Sebelum itu, hanya asisten dosennya yang masuk menggantikan dosennya mengajar. Saat itu, kami selalu diberikan banyak tugas oleh asisten dosennya, tapi ketika dosennya masuk, tugas yang kami kerjakan salah semua kak. Apa yang disampaikan oleh dosennya berbeda dengan apa yang disampaikan oleh asisten dosennya. Sehingga kami harus membuat ulang tugas yang diberikan sejak minggu pertama".

Sedangkan mahasiswa yang lain berinisial V menjelaskan, bahwa "Kalau tugas yang diberikan oleh ibu dosen itu kurang jelas, tugasnya serba salah dan menjelaskanya juga kurang jelas kak. Kadang udah capek bikin tugas, saat di cek tau-tau salah. Saat itu aku jadi merasa kesal, badmood, dan nyesek kak. Materi yang diajarkan dalam mata kuliah dasar desain itu tentang pengertian desain, unsur-unsur desain, prinsip-prinsip desain dan macam-macam warna. Ada sebagian yang bisa dipahami dan ada yang tidak. Biasanya saat ibuk memberikan tugas langsung banyak, saya kurang paham kak. Materi yang menurut saya sulit yaitu tentang value warna. Karena sulit aja membedakan warna yang sudah dicampur. Dan yang paling susah yaitu saat pencampuran warna intermediet. Media pembelajaran yang pernah diajarkan yaitu powerpoint, tetapi hanya beberapa kali.

Mahasiswa S juga menjelaskan bahwa, "Belajar dasar desain itu tugasnya tidak ada yang beres kak. Dosen dengan asisten dosennya tidak sejalan atau sepemikiran. Apa yang disampaikan dosennya berbeda dengan apa yang disampaikan asistennya. Saya tidak mengerti dengan apa yang diajarkan dosennya dan tidak paham dengan tugas yang diberikan. Materi yang diajarkan juga simpang siur dan saya benar-benar tidak mengerti. Dan asisten dosennya lebih banyak menjelaskan materinya dibanding dosennya sendiri." 
Dari hasil wawancara di atas dapat disimpulkan bahwa ada beberapa permasalahan yang terdapat pada proses pembelajaran mata kuliah Dasar Desain mahasiswa PKK Tata Busana Angkatan 2017. Pertama, waktu perkuliahan yang tidak efektif yaitu dapat dilihat dari seringnya dosen pengampu mata kuliah tidak hadir dalam proses pembelajaran. Meskipun ada asisen dosen yang menggantikan dosennya, mahasiswa tidak begitu memahami apa yang dijelaskan oleh asisten dosennya.

Kedua, perbedaan persepsi antara dosen dengan asisten dosennya yang mengakibatkan mahasiswa menjadi bingung dengan apa yang harus dikerjakan. Ini diketahui saat mahasiswa diberi tugas. Instruksi yang diberikan oleh dosen pengampu mata kuliah Dasar Desain tidak sama dengan yang diberikan oleh asisten dosen tersebut yang berakibat mahasiswa menjadi selalu bingung dan selalu salah dalam mengerjakan tugas yang diberikan. Sehingga mahasiswa selalu disuruh untuk mengulang membuat tugas yang telah mereka buat sebelumnya.

Ketiga, materi yang diberikan oleh asisten dosen saat belajar mata kuliah Dasar Desain sulit dimengerti oleg mahasiswa. Sehingga mengakibatkan mahasiswa menjadi tidak paham akan materi yang disampaikan oleh asisten dosen tersebut. Keempat, tidak ada media pembelajaran yang menjadi standar dalam pembelajaran. Ini terlihat jelas dari penjelasan mahasiswa bahwa dosen hanya mengajar dengan menjelaskan di depan kelas menggunakan papan tulis dan sesekali menggunakan infocus. Dan tidak ada buku yang digunakan untuk dijadikan sebagai acuan dalam pembelajaran.

Berdasarkan kondisi di atas, dapat disimpulkan bahwa mahasiswa PKK Tata Busana angkatan 2017 mengalami hambatan dalam belajar dalam belajar mata kuliah Dasar Desain dan tidak mampu menguasai materi pelajaran dengan baik. Penulis juga menduga bahwa hambatan belajar yang dialami oleh mahasiswa PKK Tata Busana angkatan 2017 tersebut dalam mata kuliah Dasar Desain disebabkan oleh beberapa faktor.

Hambatan tersebut terletak pada faktor minat dan kesiapan yang ada dalam faktor-faktor internal yang mempengaruhi belajar yang dijelaskan oleh Slameto (2010, 57-59). Dimana minat merupakan kecenderungan seseorang yang tetap untuk memperhatikan dan mengenang beberapa kegiatan. Minat berpengaruh besar terhadap belajar, karena minat dapat menambah keinginan seseorang untuk
Gorga Jurnal Seni Rupa

Volume 08 Nomor 01 Januari-Juni 2019

p-ISSN: 2301-5942 | e-ISSN: 2580-2380

belajar. Dan kesiapan merupakan suatu kesediaan untuk memberi respon yang timbul dari dalam diri seseroang dan juga berhubungan dengan kematangan. Kesiapan juga perlu diperhatikan dalam belajar, karena jika seorang siswa memiliki kesiapan maka hasil belajarnya akan baik. Dengan demikian, peneliti merasa perlu untuk mengangkat masalah ini dikarenakan ingin mengetahui mengenai "HambatanHambatan Belajar yang Mempengaruhi Hasil Belajar Mahasiswa dalam Pembelajaran Mata Kuliah Dasar Desain Jurusan IKK FPP UNP”.

\section{KAJIAN TEORI}

\section{Belajar dan Pembelajaran 1).Belajar}

Pada dasarnya belajar merupakan suatu kegiatan berupa proses yang dilakukan oleh setiap orang dalam kehidupan sehari-hari yang bertujuan untuk merubah sikap atau tingkah laku seseorang menjadi lebih baik dari yang sebelumnya. Adapun pengertian belajar menurut para ahli adalah sebagai berikut.

Menurut Slameto (2010:2), "Belajar ialah suatu proses usaha yang dilakukan seseorang untuk memperoleh suatu perubahan tingkah laku yang baru secara keseluruhan, sebagai hasil pengalamannya sendiri dalam interaksi dengan lingkungannya. "Menurut Muhibbin (2012:113), "Belajar memiliki arti penting bagi siswa dalam: 1) melaksanakan kewajiban keagamaan, 2) meningkatkan derajat kehidupan dan 3) mempertahankan dan mengembangkan kehidupan”.

\section{2).Pembelajaran}

Pembelajaran merupakan suatu kegiatan yang melibatkan peserta didik dalam upaya memperoleh pengetahuan, keterampilan dan nilai-nilai positif dengan memanfaatkan berbagai sumber untuk belajar (Rudi, 2009: 1). Menurut Sugihartono (2013: 73), "Pembelajaran merupakan cara yang dilakukan untuk menciptakan suasana belajar dengan baik sehingga proses memperoleh pengetahuan peserta didik berjalan dengan lancar".

\section{Hasil Belajar}

Sudjana (2005:22) menyampaikan bahwa, "Hasil belajar adalah kemampuan-kemampuan yang telah dimiliki oleh siswa setelah ia mengalami proses belajarnya". Dalam proses belajar mengajar, seorang guru atau pendidik melakukan tugasnya tidak hanya menyampaikan materi, tetapi ia juga dituntut untuk membantu keberhasilan dalam menyampaikan materi pelajaran yaitu dengan cara mengevaluasi hasil belajar mengajar. 


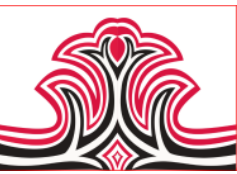

Jadi jika dikaitkan dengan mata kuliah dasar desain, maka dapat disimpulkan bahwa hasil belajar mata kuliah dasar desain yaitu hasil akhir yang diperoleh mahasiswa setelah mengalami proses belajar mata kuliah dasar desain yang ditandai dengan skala nilai berupa huruf atau simbol dan hal ini biasa dijadikan sebagai tolak ukur berhasil atau tidaknya mahasiswa tersebut dalam pembelajaran mata kuliah dasar desain.

\section{Pengertian Hambatan}

Pada proses belajar, untuk dapat mencapai tujuan dalam belajar mahasiswa sering dihadapkan pada hambatan-hambatan yang dapat mempengaruhi pelaksanaan proses belajar. Dalam kehidupan seharihari, hambatan sering dikenal dengan istilah halangan. Hambatan memiliki arti yang begitu penting dalam melakukan setiap kegiatan. Hambatan dapat menyebabkan pelaksanaan suatu kegiatan menjadi terganggu.

Hambatan belajar pada dasarnya suatu gejala yang tampak ke dalam berbagai jenis manifestasi tingkah laku. Gejala hambatan itu dimanifestasikan secara langsung dalam berbagai bentuk tingkah laku (Yani, 2012:15). Menurut Oemar (1992:72), "Hambatan adalah segala sesuatu yang menghalangi, merintangi, menghambat yang ditemui manusia atau individu dalam kehidupannya sehari-hari yang datangnya silih berganti, sehingga menimbulkan hambatan bagi individu yang menjalaninya untuk mencapai tujuan".

Berdasarkan pendapat diatas dapat disimpulkan bahwa hambatan adalah suatu hal yang bersifat negatif yang dapat menghambat atau menghalangi kegiatan yang dilakukan oleh seseorang. Hambatan ini menjadi sebuah rintangan seseorang dalam melakukan kegiatan tertentu.

\section{Faktor-Faktor yang Mempengaruhi Belajar}

Muhibbin (2012: 145) mengungkapkan, bahwa faktorfaktor yang mempengaruhi belajar siswa secara global dapat dibedakan menjadi tiga macam, yakni:

1) Faktor internal, yaitu suatu keadaan atau kondisi jasmani dan rohani siswa,

2) Faktor eksternal, yaitu suatu kondisi ligkungan yang ada di sekitar siswa,

3) Faktor pendekatan belajar siswa yang terdiri atas strategi dan metode yang digunakan oleh siswa untuk melakukan kegiatan pembelajaran.

Sedangkan menurut Djaali (2011: 101), "Di dalam proses belajar, banyak faktor yang mempegaruhinya, antara lain motivasi, sikap, minat, kebiasaan belajar dan konsep diri”.
Gorga Jurnal Seni Rupa

Volume 08 Nomor 01 Januari-Juni 2019

p-ISSN: 2301-5942 | e-ISSN: 2580-2380

Dari pendapat di atas, dapat disimpulkan bahwa faktor-faktor yang memperngaruhi belajar terdiri atas, Faktor Internal yang didalamnya terbagi atas Faktor Jasmaniah (kesehatan dan cacat tubuh), Faktor Psikologis (Inteligensi, Perhatian, Minat, Bakat, Motif, Kematangan dan Kesiapan) serta Faktor kelelahan dan Faktor Eksternal yang terbagi atas Faktor Keluarga, Faktor Sekolah dan Faktor Masyarakat. Pada pembahasan kali ini, penulis hanya akan membahas lebih dalamdua faktor yang mempengaruhi belajar pada faktor internal yang menjadi bagian dari faktor Psikologis yaitu Minat dan Kesiapan.

\section{1).Minat}

\section{(1).Pengertian Minat}

Minat adalah kecenderungan yang tetap untuk memperhatikan suatu hal atau kegiatan yang disertai dengan rasa senang. Menurut Djaali (2011:121), "Minat adalah rasa lebih suka dan rasa ketertarikan pada suatu hal atau aktivitas, tanpa ada yang menyuruh. Minat pada dasarnya adalah adalah penerimaan akan suatu hubungan antara diri sendiri dengan sesuatu diluar diri”. Muhibbin (2007:136) mengungkapkan, "Minat merupakan kecenderungan dengan kegairahan yang tinggi atau keinginan yang besar terhadap sesuatu".

Jadi, dapat disimpulkan bahwa minat adalah sebuah rasa keinginan atau rasa ketertarikan yang besar terhadap suatu hal atau aktivitas yang dimiliki oleh seseorang yang membuatnya memberikan perhatian kepada suatu hal atau aktivitas tertentu. Jika minat dikaitkan dengan proses belajar, maka dapat dikatakan bahwa minat belajar adalah rasa keinginan atau ketertartikan yang besar yang dimiliki oleh seorang mahasiswa dalam sebuah proses pembelajaran sehingga ia dapat memberikan perhatian kepada pelajaran tersebut.

\section{(2).Jenis-Jenis Minat}

Sukardi (2003:122) mengklarifikasikan minat menjadi empat macam, antara lain:

a. Expressed interest, yaitu minat yang dapat diekspresikan melalui verbal yang menunjukkan apakah seseorang menyukai atau tidak menyukai suatu objek atau aktivitas tertentu.

b. Manifest interest, yaitu minat yang dapat disimpulkan dari keikutsertaan individu pada suatu kegiatan.

c. Tested interest, yaitu minat yang dapat disimpulkan dari tes pengetahuan atau keterampilan dalam suatu kegiatan. 


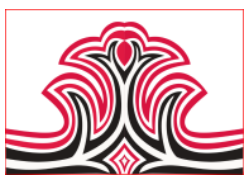

d. Inventoried interest, yaitu minat yang diungkapkan melalui inventori minat atau daftar aktivitas dan kegiatan yang sama dengan pernyataan.

\section{(3).Faktor-Faktor yang Mempengaruhi Minat}

Dalam belajar, ternyata terdapat faktor-faktor yang dapat mempengaruhi minat seorang mahasiwa seperti yang diungkapkan oleh beberapa ahli berikut ini. Muhibbin (1999:43) menjelaskan bahwa faktor yang dapat mempengaruhi minat yaitu faktor instrinsik (yang berasal dari dalam diri siswa) yang dapat mendorongnya untuk melakukan tindakan belajar, yang meliputi perasaan menyenangi materi dan kebutuhan terhadap materi tersebut serta faktor ekstrinsik (yang berasal dari luar diri siswa) yang mendorongnya untuk melakukan kegiatan belajar seperti lingkungan masyarakat, suri tauladan orang tua dan cara mngaja guru.

Rumini (1998:121) menjelaskan bahwa minat dapat dipengaruhi oleh beberapa faktor, seperti pekerjaan, sosial, ekonomi, bakat, umur, jenis kelamin, pengalaman, kepribadian dan lingkungan.

Jadi, dapat disimpulkan bahwa faktor-faktor yang dapat mempengaruhi minat belajar seseorang itu ada dua, yaitu faktor instrinsik yang mempengaruhi minat dari kecenderungan seseorang terhadap suatu hal yang di sukai dan faktor ekstrinsik yang mempengaruhi kecenderungan seseorang terhadap suatu hal berdasarkan pengaruh dari orang lain.

\section{2).Kesiapan}

Menurut Slameto (2010:113), “Kesiapan merupakan keseluruhan kondisi seseorang yang membuatnya siap untuk memberi respon/jawaban di dalam cara tertentu terhadap suatu situasi. Penyesuaian kondisi pada suatu saat akan berpengaruh pada kecenderungan untuk memberi respon". Kondisi tersebut setidaknya akan mencangkup tiga aspek yaitu: 1) Kondisi fisik, mental dan emosinal; 2) Kebutuhan-kebutuhan, motif dan tujuan; 3) Keterampilan, pengetahuan dan pengertian lainnya yang telah dipelajari.

Jadi, dapat disimpulkan bahwa kesiapan belajar merupakan suatu kondisi awal dari kegiatan belajar yang membuat seseorang siap untuk memberi jawaban atas yang ada pada diri mereka untuk mencapai suatu tujuan pembelajaran. Apabila kesiapan belajar mahasiswa baik, maka kemungkinan akan diperoleh pencapaian hasil belajar sesuai dengan yang diinginkan.
Gorga Jurnal Seni Rupa

Volume 08 Nomor 01 Januari-Juni 2019

p-ISSN: 2301-5942 | e-ISSN: 2580-2380

\section{Dasar Desain}

\section{1).Konsep Dasar Desain}

Yenni dan Riny (2017: 1) menjelaskan bahwa desain berasal dari bahasa Inggris yaitu design yang berarti rancangan, rencana atau rekarupa. Dari kata design, mucul kata 'desain' yang artinya mencipta, memikir atau merancang. Desain biasa diterjemahkan sebagai seni terapan, arsitektur dan berbagai pencapaian kreatif lainnya. Kata "desain" dapat digunakan sebagai kerja maupun kata benda dalam sebuah kalimat. Dalam kata kerja "desain" diartikan sebagai "proses untuk membuat dan menciptakan objek baru". Sedangkan dalam kata benda, "desain" digunakan untuk menyebut hasil akhir dari sebuah proses kreatif, baik itu berwujud sebuah rencana, proposal, maupun berbentuk benda nyata.

Desain adalah penataan atau penyusunan berbagai garis, bentuk, warna dan figur yang diciptakan agar mengandung keindahan. Salah satu fungsinya adalah sebagai dekorasi atau untuk mempercantik bendabenda, seperti permadani, kap lampu, tirai taplak meja, vas bunga, alat-alat furnitur, keramik, porselen, barang-barang tembikar dll (Hery, 2006).

Jadi, dapat disimpulkan bahwa desain adalah sebuah rancangan yang merupakan suatu kebutuhan manusia yang dapat dilihat dalam penataan atau penyusunan dari berbagai bentuk, garis, warna dan figur yang diciptakan yang diwujudkan pada benda nyata atau perilaku manusia melalui berbagai bidang pengalaman, keahlian dan pengetahuan yang mengandung unsur keindahan serta dapat dirasakan, dilihat, didengar dan diraba.

\section{2).Jenis-Jenis Desain}

Hestiworo (2013:9) mengungkapkan bahwa desain terdiri atas dua jenis, yaitu desain struktural dan desain hiasan/dekoratif.

Desain Struktural (structural design)

Desain struktural adalah desain yang mengandung unsur-unsur seperti garis, bentuk, ukuran, warna, tekstur dan value dari suatu benda yang dapat berbentuk benda yang memiliki tiga dimensi maupun dalam bentuk gambar dari suatu benda. Desain struktural pada busana disebut dengan siuet busana (silhoutte) yang merupakan bentuk dasar dari busana.

Siluet merupakan garis luar dari sebuah pakaian tanpa bagian-bagian atau detailnya, seperti lipit, kerut, kelim, kup dan lain-lain. Siluet juga menunjukkan suatu bentuk dari sebuah pakaian yang dapat memberikan suatu karakter mode yang unik. 


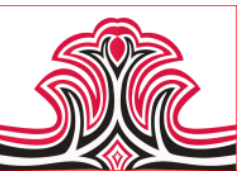

(1) Desain Hiasan (decorative design)

Desain hiasan merupakan sebuah susunan dari Garis, arah, bentuk, ukuran, warna, tekstur dan value dari suatu rancangan benda yang berfungsi untuk memperindah penampilan suatu benda. Jadi, desain hiasan adalah suatu rancangan gambar yang diciptakan untuk diterapkan sebagai hiasan pada benda pakai atau benda lainnya yang bersifa dekoratif, seperti busana dan lenan rumah tangga.

Tujuan dari desain hiasan itu sendiri adalah untuk menambah keindahan desain struktur atau siluet. Desain hiasan dapat berupa ragam hias, sulaman, garnitur dan lain-lain. Desain hiasan memiliki syaratsyarat sebagai berikut:

a. Hiasan yang digunakan tidak berlebihan

b. Letak hiasan disesuaikan dengan bentuk strukturnya

c. Memiliki cukup ruang untuk latar belakang dari benda tersebut

d. Penempatan desain hiasan disesuaikan dengan luasnya latar belakang dari benda yang dihias. Hiasan yang diberikan juga harus cocok dengan bahan desain strukturnya dan sesuai dengan cara.

\section{3).Unsur-Unsur Desain}

Suatu benda yang terlihat selalu diwujudkan oleh unsur-unsurnya, dengan kata lain terdapat unsur-unsur yang membentuknya agar terlihat dan berwujud menjadi sebuah benda. Begitu juga dengan desain yang pada dasarnya tersusun dan terdiri dari unsurunsur yang membentuknya.

Menurut Abdul (2006: 23-24) bahwa,

"Terdapat empat kelompok unsur utama desain, yaitu (1) unsur konsep, terdiri atas: titik, garis, bidang, dan gempal/bentuk trimatra, (2) unsur rupa, terdiri atas: raut, ukuran, warna dan barik (tekstur), (3) unsur pertalian, terdiri atas: arah, kedudukan, ruang dan gaya berat, dan (4) unsur peranan, terdiri atas: raut tiruan, makna dan tugas".

Sedangkan Yuliarma (2016: 104) mengungkapkan bahwa unsur desain merupakan unsur-unsur yang digunakan oleh perancang untuk mewujudkan desainnya agar orang lain dapat membaca dan menerima desain tersebut sesuai seleranya. Dalam ilmu seni rupa, unsur-unsur desain terdiri atas unsur garis, arah, bentuk, ukuran, tekstur, value, warna serta motif atau corak.

\section{4).Prinsip-Prinsip Desain}

Prinsip-prinsip desain adalah suatu cara untuk menyusun unsur-unsur sehingga tercapai perpaduan yang memberi efek tertentu (Sri, 1993: 15). Menurut
Gorga Jurnal Seni Rupa

Volume 08 Nomor 01 Januari-Juni 2019

p-ISSN: 2301-5942 | e-ISSN: 2580-2380

Widjiningsih (1982: 6), "prinsip desain merupakan suatu hukum kombinasi yakni bagaimana unsur-unsur itu disusun atau dikombinasikan untuk menghasilkan efek tertentu.

Sri (1993 : 15) menjelaskan bahwa prinsip-prinsip desain yang perlu diketahui adalah keselarasan, perbandingan, keseimbangan, irama dan pusat perhatian. Sedangkan Ernawati dkk (2008: 211) menjelaskan bahwa prinsip-prinsip yang penting dalam pembuatan desain, yaitu harmoni, proporsi, balance, irama, aksen (center of interest) dan unity.

Berdasarkan pendapat diatas, maka dapat disimpulkan bahwa prinsip-prinsip dari sebuah desain, yaitu keselarasan (harmoni), proporsi, keseimbangan (balance), irama (rhtym), pusat perhatian (center of interest) dan kesatuan (unity). Dalam pembuatan desain busana, penerapan prinsip yang tidak tepat pada pembuatan desain busana yang akan dibuat akan menghasilkan rancangan yang kurang nyaman dan kurang cantik jika dilihat.

\section{METODE PENELITIAN}

Jenis penelitian yang digunakan dalam penelitian ini adalah penelitian deskriptif kuantitatif yang bertujuan untuk untuk mengetahui dan menemukan informasi dalam mengidentifikasi hambatan mahasiswa dalam mempelajari mata kuliah dasar desain. Populasi penelitian adalah adalah seluruh mahasiswa program studi PKK Tata Busana angkatan 2017 yang berjumlah 56 orang. sampel dalam penelitian ini adalah semua mahasiswa prodi PKK Tata Busana angkatan 2017 yang telah mengikuti mata kuliah Dasar Desain, yaitu sebanyak 56 orang. Jenis data adalah data primer dan sekunder yang dikumpulkan dengan kuisioner. Analisis data terdiri dari analisis deskriptif.

\section{HASIL DAN PEMBAHASAN \\ 1.Hasil}

Hambatan belajar terhadap hasil belajar mahasiswa PKK keahlian Tata Busana angkatan 2017 pada pembelajaran mata kuliah dasar desain, dilihat dari minat dan kesiapan belajar.

Gairah belajar mahasiswa dalam pembelajaran mata kuliah Dasar Desain Jurusan IKK FPP UNP adalah 4,01 dengan persentase $80,24 \%$, termasuk kategori baik. Keinginan belajar mahasiswa dalam pembelajaran mata kuliah Dasar Desain Jurusan IKK FPP UNP adalah 4,04 dengan persentase $80,71 \%$, termasuk kategori baik. mengerjakan tugas mahasiswa 
dalam pembelajaran mata kuliah Dasar Desain Jurusan IKK FPP UNP adalah 3,88 dengan persentase 77,50\%, termasuk kategori cukup baik. Mahaiswa bertanya dalam pembelajaran mata kuliah Dasar Desain Jurusan IKK FPP UNP adalah 3,83 dengan persentase $76,67 \%$, termasuk kategori cukup baik. Keaktifan mahasiswa dalam kegiatan diskusi dalam pembelajaran mata kuliah Dasar Desain Jurusan IKK FPP UNP adalah 3,89 dengan persentase 77,86\%, termasuk kategori cukup baik.Kekatifan mahasiswa ketika ada kesempatan bertanya dalam pembelajaran mata kuliah Dasar Desain Jurusan IKK FPP UNP adalah 3,82 dengan persentase $76,31 \%$, termasuk kategori cukup baik.Perhatian mahasiswa dengan mendengarkan materi yang diajar dosen d dalam pembelajaran mata kuliah Dasar Desain Jurusan IKK FPP UNP adalah 3,83 dengan persentase 76,61\%, termasuk kategori cukup baik. Mahasiswa menambah pengetahuan di luar dalam pembelajaran adalah 3,92 dengan persentase $78,33 \%$, termasuk kategori cuku[ baik.Hal ini berarti sebagian mahasiswa menambah pengetahuan di luar kampus tentang materi Dasar Desain dan sebagian lagi tidak. Mahasiswa serius dalam pembelajaran mata kuliah Dasar Desain Jurusan IKK FPP UNP adalah 3,63dengan persentase 72,62\%, termasuk kategori cukup baik.

\section{Pembahasan}

Mahasiswa membuat catatan pinggir dalam pembelajaran mata kuliah Dasar Desain Jurusan IKK FPP UNP adalah 3,38 dengan persentase 67,68\%, termasuk kategori cukup baik. mahasiswa mencatat inti informasi dalam pembelajaran mata kuliah Dasar Desain Jurusan IKK FPP UNP adalah 3,60 dengan persentase $71,90 \%$, termasuk kategori cukup baik. mahasiswa menggarisbawahi catatan dalam pembelajaran mata kuliah Dasar Desain Jurusan IKK FPP UNP adalah 3,53 dengan persentase 70,54\%, termasuk kategori cukup baik. Kondisi kesehatan mahasiswa dalam pembelajaran mata kuliah Dasar Desain Jurusan IKK FPP UNP adalah 3,72 dengan persentase $74,46 \%$, termasuk kategori cukup baik. Mahasiswa tidak lesu dalam pembelajaran mata kuliah Dasar Desain Jurusan IKK FPP UNP adalah 3,83 dengan persentase $75,55 \%$, termasuk kategori cukup baik.

\section{KESIMPULA DAN SARAN 1.Kesimpulan}

Hambatan-hambatan belajar mahasiswa dalam pembelajaran mata kuliah Dasar Desain Jurusan IKK FPP UNP, dilihat dari minat yaitu kemauan mengerjakan tugas, kemauan bertanya, keaktifan dalam diskusi, memanfaatkan kesempatan bertanya,
Gorga Jurnal Seni Rupa

Volume 08 Nomor 01 Januari-Juni 2019

p-ISSN: 2301-5942 | e-ISSN: 2580-2380

perhatian terhadap materi kurang, kemauan menambah pengetahuan di luar dalam pembelajaran, kurang serius, tidak membuat catatan pinggir, mencatat informasi dan menggarisbawahi catatan. Sedangkan dari kesiapan belajar, faktor penghambat adalah kondisi kesehatan, mahasiswa lesu, kurangnya hasrat dalam belajar, kurang percaya diri dan kurang membaca buku.

\section{Saran}

Diharapkan mahasiswa untuk mengetahui faktor yang paling dominan yang menjadi hambatan dalam belajar sehingga dapat mengatasinya. Diharapkan pada Dosen mata kuliah untuk memperhatikan minat dan kesiapan mahasiswa dalam belajar.

\section{DAFTAR RUJUKAN}

Abdul Azis Said. (2006). Dasar Desain Dwimatra. Makassar: UNM Makassar.

Dalyono. (1997). Psikologi Pendidikan. Jakarta: PT. Rineka Cipta.

Djaali. (2011). Psikologi Pendidikan. Jakarta: Bumi Aksara.

Ernawati, dkk. (2008). Tata Busana Jilid I. Jakarta: Direktorat Pembinaan Sekolah Menengah Kejuruan.

Hery Suhersono. (2006). Desain Bordir Motif Flora dan Fauna Nusantara. Jakarta: PT. Gramedia Pustaka Utama.

Hestiworo. (2013). Dasar Desain I. Jakarta: Diktorat Pembinaan SMK (2013).

Muhibbin Syah. (2012). Psikologi Belajar. Jakarta : Raja Grafindo Persada.

(1999). Psikologi Belajar. Jakarta :

PT. Raja Grafindo Persada.

Oemar Hamalik. (1992). Psikologi Belajar Mengajar. Bandung: Sinar Baru Algesindo.

Rudi Susilana. (2009). Media Pembelajaran. Bandung: Alfabeta.

Rumini, dkk. (1998). Psikologi Umum. Yogyakarta : FIP IKIP.

Slameto. (2010). Belajar dan Faktor-faktor yang Mempengaruhinya. Jakarta: PT. Rineka Cipta.

Sri Widarwati. (1993). Desain Busana I. Yogyakarta: Fakultas Teknik Universitas Yogyakarta.

Sudjana. (2005). Metode Statistika. Bandung: Transito.

Sugihartono, dkk. (2013). Psikologi Pendidikan. Yogyakarta: UNY Press.

Sukardi. (2003). Metodologi Penelitian Pendidikan. Yogyakarta: PT. Bumi Aksara.

UNP. (2015). Peraturan Akademik Universitas Negeri Padang. Padang: UNP. 
Widjiningsih. (1982). Desain Hiasan dan Lenan Rumah Tangga. Yogyakarta : FPTK IKIP.

Yani Dwi Ningsih. (2012). Hambatan-hambatan Belajar Siswa Pada Mata Pelajaran Membuat Pola (Pattern Making) Dengan Teknik Konstruksi di SMK Negeri 1 IV Angkek Kab. Agam. Skripsi. Padang: FT UNP.

Yenni Idrus dan Riny Arviana. (2017). Desain Ragam Hias Berbantuan CorelDraw. Bandung: ITB Press.

Yuliarma. (2016). Dasar-dasar Teknik Pembuatan Busana. Padang: UNP Press. 